ISSN: 1110-5623 (Print) - 2090-0570 (Online)

\title{
EFFECT OF IN-OVO INJECTION WITH IRON-METHIONINE CHELATES OR IRON NANO-PARTICLES AND POST HATCH DIETARY FOLIC ACID ON GROWTH PERFORMANCE AND PHYSIOLOGICAL RESPONSES OF BROILER CHICKENS
}

\author{
E. A. El-Said ${ }^{1}$ and M. R. El-Gogary ${ }^{2}$
}

${ }^{1}$ Dep.of Poult. Prod., Fac. of Agric., Damietta Uni., Egypt.

${ }^{2}$ Dep. of Poult. Prod., Fac. of Agric., Mansoura Uni., 35516, Egypt.

Corresponding Author: M. R. El-Gogary E-mail: melgogary@mans.edu.eg

Received: 22/09/2019

Accepted: $27 / 10 / 2019$

\begin{abstract}
A study was carried out to evaluate the effect of in-ovo injection of ironmethionine chelates (Fe-Meth) or iron nano-particles (FeNPs) and post hatch feeding with diets fortified with folic acid on productive performance and some physiological responses of Ross broiler chickens. A total of 450 fertile eggs were allocated to 5 treatment groups in the incubator, each of which included 3 replicates (30 eggs each). Experimental treatments consisted of a $5 \times 2$ factorial arrangement design with 5 levels of in-ovo injection solutions at day seven of incubation and two dietary levels of folic acid (FA) $(0.0$ or $0.5 \mathrm{~g} / \mathrm{kg}$, diet $)$ after hatching. In-ovo injection treatments were divided into 5 groups: control non- injected (T1), injected with $0.1 \mathrm{ml}$ physiological saline (T2), sham-injected control (T3), injected with $0.1 \mathrm{ml}$ of $75 \mathrm{ppb}$ of iron nanoparticles (T4, FeNPs), while the last group (T5) was injected with $0.1 \mathrm{ml}$ of $75 \mathrm{ppb}$ organic iron (Fe- meth). Results showed that in-ovo injection of different iron sources significantly improved live body weight and weight gain of broiler chicks, and enhanced FCR at 3 and 5 weeks of age compared to other groups. Broilers fed folic acid fortified diets displayed significantly heavier Live body weight (LBW) and body weight gain (BWG) than the those fed the control unsupplemented diet. The combined interaction effect of in-ovo iron injection and dietary folic acid supplementation showed the best productive performance figures during the whole experimental period. Different iron sources had no significant effect on all plasma protein fraction, Lipids profile except a higher concentration of high density lipoprotein (HDL) in plasma recorded inovo injection of different iron sources compared with different controls. Plasma hemoglobin, globulin fractions $(\alpha, \beta$, and $\gamma$-globulin), transferrin and Tri-iodothyronine concentration were significantly higher in both injected groups compared to the different control groups. Birds fed FA treatment recorded the lower significant values of plasma cholesterol, triglyceride and LDL, but, the birds fed FA recorded the higher significant value of plasma HDL, plasma hemoglobin, globulin fractions $(\alpha, \beta$, and $\gamma$-globulin), transferrin and tri-iodothyronine concentration levels compared with birds fed with or without FA.

In conclusion, in-ovo injection of Fe-Meth. or FeNPs and fed the diet fortified with FA were sufficient to improve broiler performance or physiological response in broiler chickens.
\end{abstract}

Key words: nano-particles elements - broiler performance - physiological response. 


\section{INTRODUCTION}

Minerals and trace elements are most important for many digestive, physiological and biosynthetic processes in the body. Iron $(\mathrm{Fe})$ is a trace element essentially required within the body for many functions. Iron is an important trace element in that either a deficiency or an excess can compromise the immune system. It has been well documented that serum iron falls early in response to bacterial and viral infections and rebounds quickly with recovery (Menendez et al. , 1997). Iron plays an essential role in many metabolic processes including oxygen transport, oxidative metabolism and cellular growth, since its balance is rigorously controlled by the regulation of absorption Shinde (2011). Iron is essential for a variety of physiological processes in livestock (e.g. DNA synthesis, oxygen transport, etc.) as reported by Lozoff et al. (2006); Whitnall and Richardson (2006) and $\mathrm{Li}$ and Zhao (2009).

Iron is important form all forms of life and considered to be a principal oligo-element of the body. Iron is a chemical element that has several vital functions in the body. It is an essential trace element for broiler growth, which is involved in numerous energy metabolisms, neurotransmitter synthesis and phagocyte antimicrobial activity, as well as in the synthesis of DNA, collagen and bile acids (Quintana et al., 2006). Research on organic minerals proved that chelate minerals can be more effectively absorbed in the intestines than inorganic oxide and sulfate (Wedekind et al. 1992; Aoyagi and Baker 1993).

Nanotechnology is the emerging field to study the control of an elemental molecular scale in pursuing positive responses when fed alternative to the conventional minerals' sources Diamond et. al (2018). Zhai et al. (2015) reported that in-ovo injection of Fe-nano (25$125 \mathrm{ppm})$ improved chick performance traits.

Folic acid is essential in the transfer of mono-carbonate units in metabolic processes, affecting the synthesis of purines and pyrimidines, which make up the nucleic acids needed for cell division. It is also involved in the metabolism of serine, glycine, histidine, methionine, choline and thiamine Barroeta et al.(2012). Folic acid is especially important in tissues active in protein synthesis and cell division. It participates in the increase of nuclei in muscle cells Isabel (2012).

The main objective of the present study was to investigate the effect of in-ovo injection with different iron sources and post hatch dietary supplementation of folic acid on productive performance and some blood parameters of broiler chicks.

\section{MATERIALS AND METHODS}

The current study was carried out in a private poultry farm near Daqahlia Governorate, Egypt. A total of 450 fertile broiler eggs $(65.0 \pm 0.58 \mathrm{~g})$ obtained from a commercial Ross parent stock were randomly divided into five equal groups. The first one (T1)was kept as a control (without injection), the $2^{\text {nd }}(\mathrm{T} 2)$ was injected with $0.1 \mathrm{ml}$ saline $9.0 \%$, the $3^{\text {rd }}$ (T3) was sham-injected (only punctured), while the $4^{\text {th }}(\mathrm{T} 4)$ and $5^{\text {th }}$ groups were injected with $0.1 \mathrm{ml} /$ egg containing 75 ppb of FeNPs and Fe-Meth, respectively. All eggs were normally incubated at 37.6 ${ }^{\circ} \mathrm{C}$ and $55 \%$ relative humidity $(\mathrm{RH})$ in an automatic incubator. Egg injection procedure was carried out at day 7 of embryonic development. Thus, the large end of each egg (location of air cell) was disinfected by ethyl alcohol. The point site of injection was punctured by hard and thin stylus and the tested material was 
nano-particles elements - broiler performance - physiological response.

injected into the air cell of each egg by using graded insulin syringe $(1 \mathrm{ml})$ and the punctured site was sealed with non-toxic glue sticks. At the $18^{\text {th }}$ day of incubation, all eggs were transferred to the Hatcher and kept till hatching at $36.5^{\circ} \mathrm{C}$ and $70 \% \mathrm{RH}$. Hatchability percentage was recorded after hatching $(87.8$ $\%)$.

Only 60 hatched chicks from each treatment were randomly chosen then each treatment sub-divided into two dietary folic acid (30 chicks each in 3 replicates of ten chicks). Folic acid was supplied in diet of newly hatched chicks at two levels 0.0 (without, control) or 0.5 $\mathrm{g} / \mathrm{Kg}$ diet. Since 10 experimental treatments were existed ( 2 folic acid levels X 5 in-ovo injection treatments). All chicks were fed $a d$ libitum on commercial starter (1 to $21 \mathrm{~d}$ ) and grower (22-35d) diets. The birds were given the same management and vaccination program as those done in commercial farms. The experimental diets were formulated to satisfy the recommended doses of broiler chickens nutrition according to NRC (1994). Feed in mash form and fresh water were given freely. The composition and chemical analysis of the experimental diets are shown in Table 1.Chicks were individually weighed at hatch and weekly until the end of the experimental period and their LBW were recorded. Body weight gain (BWG) and feed conversion ratio (FCR) were then calculated.

\section{Slaughter traits}

At $35 \mathrm{~d}$ of age, three chicks from each replicate were randomly chosen, weighted and slaughtered for carcass traits measurements. Internal organs (gizzard, Abdominal fat, heart, liver) and lymphoid organs (spleen, thymus and Bursa) weights were recorded to the nearest 0.1 gram. The relative weights of these organs were calculated in relation to live body weight.

\section{Physiological traits \\ 1-Blood parameters}

At the end of the growing experiment (5 weeks of age) blood samples were collected from 3 chicks per each treatment in heparinized tubes, centrifuged (4000 rpm) for 15 minutes, then clear plasma samples were decanted and stored in a deep freezer at $-20^{\circ} \mathrm{C}$ until the time of biochemical analysis. Total protein (Grant et al., 1987), albumin (Doumas, 1971), and different types of globulin ( $\alpha$-globulin, $\beta$ globulin and $\gamma$-globulin) were determined according to Bossuyt (2006). Plasma cholesterol (Stein et al., 1986), triglycerides (Fossati and Prencipe, 1982), and HDL (Lopez-Virella,1977) and transferrin were determined by commercial Kits (Spectrum Diagnostic Kits, Spec. Corp. Egypt), while LDL was determined according to the formula of Friedewald et al. (1972).

Hematological parameters including red blood cells count, packed cell volume (hematocrit)and hemoglobin concentration were measured immediately after blood collection.

Hemoglobin concentration and red cell indices (MCH and $\mathrm{MCHC}$ ) were determined according to the following equations:

Mean Corpuscular Hemoglobin $(\mathrm{MCH})(\mathrm{Pg})$ $=\mathrm{HbX10/Red} \mathrm{blood} \mathrm{cell.} \mathrm{Mean} \mathrm{Corpuscular}$ Hemoglobin Concentration $(\mathrm{MCHC})(\mathrm{g} / \mathrm{dl})=$ HbX100/ Packed cell volume

\section{2-Blood hormones:}

Tri-iodothyronine (T3) was measured by ELISA technique using IMMUNOSPEC kits.

\section{Statistical analysis}

The design of all the experiments in this study was completely randomized design. Data were statistically analyzed as factorial design arrangement $(2 \times 5)$ by two-way analysis of variance using SAS program (SAS, 2006). Differences between means were detected according to DunnettTukey-Kramer Range test due to unequal number of chicks in different groups.

\section{RESULTS AND DISCUSSION}

\section{Productive performance:}

Results in Table $2 \& 3$ showed the effect of in-ovo injection of different iron sources and dietary supplementation of folic acid on broiler chickens' performance at three and five weeks of age. Chicks delivered from eggs which injected with different iron sources had significantly heavier live 
body weights (LBW) and weight gain compared to the other treatment groups either at three or five weeks of age. This trend was also observed for the folic acid effect, regardless in-ovo treatments, where folic acid improved significantly LBW, FI and weight gain compared with the broiler without supplementation folic acid. This is in agreement with El-Husseiny et al. (2007) who found that body weight gain and the efficiency of feed conversion were significantly increased linearly with increasing folic acid level. Sahin et al. (2003) found that the folic acid supplementation with increased feed intake improved the growth rate in Japanese quail. Moreover, both in-ovo injection of different iron sources, and folic acid supplementation significantly enhanced FI and FCR during the starter and whole experimental periods as compared to other groups. This agrees with Zhai et al. (2015) who found that inovo injection, into the egg yolk sac, with 25, 75, 125 ppm Fe-Nano improved embryonic growth and increased chick body weight compared with the other treatments. Similar results were also observed by using iron oxide nanoparticles due to their general stability in air and their ability to be degraded or metabolized in vivo, making them excellent candidates for a large variety of applications as reported by Bronstein et al.(2007). In this respect Marinov (2011) reported that the trace element iron is of great importance to fast growing animals, such as the broiler chickens, although the protein sources in the compound feed of the broiler chickens contain high levels of iron, which prevent them from iron deficiency anemia. On the other hand, Foye et al. (2006) and Uni et al. (2005) reported that in-ovo feeding of chick embryos could lead to improve of digestion responses of broilers and increase nutrients utilization. Also, Pek et al. (2005)who determined the effects of different amounts of iron on body weight gain, feed consumption, feed efficiency and some blood parameters and reported that supplementation of $100 \mathrm{mg} / \mathrm{kg}$ feed $\mathrm{Fe}$ significantly increased body weight gain, feed consumption and feed efficiency in quail. Moreover, Talpur et al. (2016) showed that Fe supplemented feed was more effective to produce higher live body weight gain as compared to control and with increasing $\mathrm{Fe}$ level, the feed intake of broilers was decreased. However, Bakyaraj et al. (2012), Cai et al. (2012) and Choupani et al. (2013) who reported insignificant differences in FCR between birds fed different nano-iron forms and those fed the control diets.

Carcass yield and organic immunity

The data of carcass parameters are shown in Table 4. It could be detected that inclusion of in-ovo injection of different iron sources and supplementations of folic acid. In the broiler diet did not have significant effect on gizzard and heart. However, the experimental groups in-ovo injection of different iron sources achieved significantly higher LBW and the proportions of carcass and liver or immunity organs (spleen and thymus). Nevertheless, abdominal fat was significant lower compared with different control groups, significant lower abdominal fat percentage compared with different control groups. On the other hand, broilers fed the diet fortified with folic acid $(0.5 \mathrm{~g} / \mathrm{kg})$ or without folic acid showed insignificant effect on carcass trait or the relative weight of immune organs. Kwiecień et al.(2015) how found that no significant differences in slaughter yield or in the share of breast muscles, leg muscles and liver in the carcass were 
nano-particles elements - broiler performance - physiological response.

recorded between the diets were supplemented with the organic form iron (Fe-Gly at the rate of $25 \%, 50 \%$ or $100 \%$ of the total requirements of the elements) and inorganic $\mathrm{Fe}(\mathrm{FeSO} 4$ at the rate of $50 \%$ or $100 \%)$. While, Nouri et al.(2018)who found that no difference detected on carcass characteristics in birds in-ovo injected with folic acid on day 42 post hatch.

\section{Plasma proteins and lipids concentration:}

Results in Tables 5. showed the effect of in-ovo injection of different iron sources and supplementation of folic acid on plasma protein and lipids fractions of broiler chick at five weeks of age. The results showed that no significant effect on total plasma protein level. Conversely, chicks from the negative control (Sham) treatment has significantly higher albumin level compared to other groups. Plasma globulin level was significantly higher for chicks from iron injected groups compared with treatments. Moreover, results revealed insignificant effects of in-ovo injection with different iron sources on plasma cholesterol, triglyceride and lowdensity lipoprotein(LDL) however, high density lipoprotein (HDL) was significantly increased by treatments except the control one. It is suggested that iron overload can negatively modify the blood lipid metabolism by increasing the ability of homocysteine to create oxocholesterol in arteries and by changing the content of cholesterol and its fractions (Choi et al., 2013).

Apart from the effect of in-ovo injection, data showed that birds fed diet fortified with folic acid had no significant effects on all plasma protein fractions and triglycerides however; plasma cholesterol and LDL were significantly decreased although plasma HDL increased. The interaction between in-ovo injection and folic acid revealed insignificant effects on all blood parameters which could be explained by their independent mode of action at older age of birds.

Abd El-Azeem et al. (2014) reported inovo feeding of the FA (1 mg/egg) decreased plasma cholesterol (Cho), triglycerides (TG) and LDL levels in broiler chicken.

\section{Hematological indices:}

The hematological measurements are shown in Table 6 . The results indicate that in-ovo injection of broiler eggs with either FeNPs or Fe-Meth recorded significant increases $(\mathrm{P}<0.01)$ in the values of $\mathrm{Hb}$, RBC's, MCH and MCHC, while $\mathrm{Ht}$ and MCV values were not significantly affected. Ovo iron injection significantly $(\mathrm{P}<0.01) \quad$ enhanced hemoglobin concentration by $30.49 \%$ and $21.23 \%$ for FeNPs and organic Fe-Meth, respectively, compared with the control non- injected group. This improvement concomitant with similar increases in the other hematological indices including RBC's count, $\mathrm{MCH}$ and $\mathrm{MCHC}$ may explain the positive increase of LBW and weight gain of chicks from these groups (Table 2). Since, there is evidence that the saturation level of erythrocytes in terms of $\mathrm{MCH}$ and MCHC are related to more oxygen consumption and subsequent efficient nutrients metabolism and utilization by living organism.

Furthermore, broiler fed basal diet supplemented with folic acid had significantly higher $\mathrm{Hb}$ and $\mathrm{MCH}$ values than the other groups, however, $\mathrm{Ht}$, RBC's, MCHC and MCV values did not differ significantly the un-supplemented control group.

On the other hand, all the hematological parameters (except $\mathrm{Hb}$ and $\mathrm{MCH}$ ) did not significantly influenced by the interaction 
between in-ovo injection with iron and folic acid supplementation to diet. It is well documented that the increased hemoglobin content in the blood may be due, in part to, the effect of intensification of oxidation and reduced haeme phagocytic processes in the chicken's spleen especially those receiving FeNPs and folic acid. Previous studies showed that the increased concentration of hemoglobin was usually accompanied by an increased number of RBC (Sosnowska et al., 2013). Iron absorption into the body and its incorporation to hemoglobin (Fox 2003, Mullally et al. 2004). Iron has a role in modulating iron superoxide dismutase activity and hydrogen peroxide generation, furthermore, iron availability controls the expression of Leishmania iron transporter1, resulting in iron uptake and an overall increase in intracellular iron availability (Mittra et al., 2013).

On the other hand, folic acid is reported as an essential nutrient for animal's hematopoietic activity, regulation of blood glucose, improvement of cell membrane activity and finally eggs' hatchability (Halver and Hardy, 2002; and Halver, 1989). Thus, any deficiency in this factor leads to different physiological dysfunctions, including megaloblastic anemia, increased appetite and weight loss (Cowey and Woodward, 1993). In general, the present results, are in agreement with Soheil et al. (2013) who found that folic acid treatment had different effects on RBC factors.

\section{Plasma globulin fractions, transferring and tri-iodothyronine hormone}

Results in Table 7. showed the effect of ovo injection of different iron forms and supplementation of folic acid on plasma globulin fractions, transferring and triiodothyronine hormone concentrations of broiler chicks at five weeks of age. Plasma globulin fractions $(\alpha, \beta$, and $\gamma$-globulin), transferrin and tri-iodothyronine concentration were significantly higher in both iron- injected groups compared to the different control groups. A similar trend was also observed for transferrin and triiodothyronine hormone levels. Moreover, broilers fed the diet fortified with folic acid $(0.5 \mathrm{~g} / \mathrm{kg}$ diet $)$ had significantly higher levels of plasma globulin fractions $(\alpha, \beta$, and $\gamma$ globulin), transferrin concentration and triiodothyronine hormone compared to broilers fed the control basal diet. However, the interaction effect wasn't significant.

The previous results support the earlier knowledge concerning the role of folic acid in modulating growth via its physiological influence in synthesis of nucleic acids, specific role in tyrosine metabolism i.e. thyroid hormones synthesis, immunity and hematopoiesis (Harper et al,.1970 and Hutson et al., 1981). On the other hand, our results showed promising application of in-ovo iron injection as a practical tool to improve growth performance, immunity and the general physiological homeostasis which benefits both chicken health and broiler producers net revenue. These results are in close agreement with those reported by many authors who discussed the role of iron and (or) folic acid administration in different poultry production criteria (Ji et al. 2007, 2009; Soheil et al.,2013 ; Mittra et al., 2013 ; Mogahid, et al.,2019). Soluble transferrin receptor is a new marker of iron status and erythropoietic activity (Schumacher et al., 2002). Additionally, plasma transferrin saturation might be expected to provide a more sensitive index of iron status in blood (Finch et al., 1977). But, to our knowledge, the present study may be the first one dealing with the combined effect of pre-hatch in-ovo iron injection and post hatch folic acid supplementation to broiler diets.

\section{CONCLUSION}

It could be concluded that a combined application of in-ovo iron injection with folic acid enrichment of diets could be used as a promising practice to improve growth and immune response of broiler chicks. Iron nano-particles ovo injection gave the best results under the prevailing conditions of this study. 
nano-particles elements - broiler performance - physiological response.

Table(1): Composition and Chemical Analysis of the Basal Diets.

\begin{tabular}{|l|c|c|}
\hline Ingredients (\%) & Starter diet & Grower diet \\
\hline Yellow corn & 66.3 & 70.38 \\
Soybean meal, 44\% CP & 7.12 & 7.61 \\
Corn Gluten Meal, 60.2\% CP & 22.05 & 18.1 \\
Dicalcium Phosphate & 1.87 & 1.34 \\
Limestone & 1.5 & 1.52 \\
DL-methionine & 0.04 & 0.0 \\
L-Lysine HCL & 0.52 & 0.45 \\
Sodium chloride & 0.3 & 0.3 \\
Vit. + Min. Premix ${ }^{1}$ & 0.3 & 0.3 \\
Total & 100 & 100 \\
\hline Chemical analysis: (As-fed) & & \\
\hline Metabolizable energy, kcal/kg & 3200 & 3200 \\
Crude protein, \% & 23 & 21 \\
Crude Fiber, \% & 2.24 & 2.31 \\
Ether extract, \% & 3.12 & 3.18 \\
Calcium, \% & 1.01 & 0.91 \\
Nonphytate Phosphorus, \% & 0.45 & 0.35 \\
Methionine, \% & 0.53 & 0.44 \\
Meth. + Cys. (TSAA, \%) & 0.94 & 0.82 \\
Lysine, \% & 1.11 & 1.02 \\
\hline
\end{tabular}

"1 Premix contained per kg diet: A, 11000 IU; Vit. D3, 5000 IU; Vit. E, 50 mg;Vit K3, 3 mg; Vit. B1, $2 \mathrm{mg}$; Vit. B2 6 mg; B6 3 mg; B12, 14 mg;Nicotinicacid 60mg; Folicacid 1.75 mg, Pantothenicacid 13mg; Biotin $120 \mathrm{mcg}$,Choline $600 \mathrm{mg}$; Copper $16 \mathrm{mg}$; Iron 40 mg;Manganese. $120 \mathrm{mg}$; Zinc $100 \mathrm{mg}$ and Iodine $1.25 \mathrm{mg}$ 
Table (2): Productive response of broiler chicks to pre hatch in-ovo injection with organic iron or FeNPs and post hatch dietary folic acid supplementation

\begin{tabular}{|c|c|c|c|c|c|}
\hline Items & BW-0 (g) & $\begin{array}{c}\text { 3wkBW } \\
(\mathrm{g})\end{array}$ & $\begin{array}{c}\text { 5wkBW } \\
(\mathrm{g})\end{array}$ & $\begin{array}{c}\text { WG 0-3 } \\
\text { (g) }\end{array}$ & WG 0-5 (g) \\
\hline \multicolumn{6}{|l|}{ FeNPs (T) } \\
\hline Control(T1) & 44.25 & $958.3^{\mathrm{b}}$ & $2063.22^{b}$ & $914.05^{b}$ & 2018.90 \\
\hline Saline(T2) & 45.15 & $948.0^{\mathrm{b}}$ & $2061.32^{b}$ & $902.85^{b}$ & $2016.00^{\mathrm{b}}$ \\
\hline Sham(T3) & 44.74 & $985.5^{\mathrm{b}}$ & $2017.15^{b}$ & $940.77^{b}$ & $1972.62^{b}$ \\
\hline FeNPs (T4) & 43.87 & $1113.8^{\mathrm{a}}$ & $2335.46^{\mathrm{a}}$ & $1069.94^{\mathrm{a}}$ & $2291.29^{a}$ \\
\hline Fe-Met( T5) & 45.00 & $11190.0^{\mathrm{a}}$ & $2295.20^{\mathrm{a}}$ & $1074.00^{\mathrm{a}}$ & $2250.00^{\mathrm{a}}$ \\
\hline SEM. & 0.76 & 24.97 & 40.35 & 24.88 & 39.97 \\
\hline Sig. & NS & $* * *$ & *** & *** & $* * *$ \\
\hline \multicolumn{6}{|l|}{ Folic Acid (F) } \\
\hline $\mathrm{F} 1(0.0 \mathrm{~g} / \mathrm{kg})$ & 44.40 & $995.99^{b}$ & $2093.88^{b}$ & $941.52^{b}$ & $1989.40^{b}$ \\
\hline $\mathrm{F} 2(0.5 \mathrm{~g} / \mathrm{kg})$ & 44.80 & $1063.89^{\mathrm{a}}$ & $2274.95^{\mathrm{a}}$ & $1019.12^{\mathrm{a}}$ & $2230.12^{\mathrm{a}}$ \\
\hline SEM. & 0.48 & 15.79 & 25.52 & 15.74 & 25.28 \\
\hline Sig. & NS & $* *$ & $* * *$ & $* *$ & $* * *$ \\
\hline \multicolumn{6}{|c|}{ Interaction $\left(\mathbf{T}^{*} \mathbf{F}\right)$} \\
\hline $\mathrm{T} 1 * \mathrm{~F} 1$ & 44.17 & 908.3 & 1993.3 & 864.1 & 1949.1 \\
\hline $\mathrm{T} 1 * \mathrm{~F} 2$ & 44.33 & 1008.3 & 2133.0 & 964.0 & 2088.7 \\
\hline $\mathrm{T} 2 * \mathrm{~F} 1$ & 45.00 & 879.0 & 1894.0 & 834.0 & 1849.0 \\
\hline $\mathrm{T} 2 * \mathrm{~F} 2$ & 45.30 & 1017.0 & 2228.3 & 971.7 & 2183.0 \\
\hline $\mathrm{T} 3 * \mathrm{~F} 1$ & 44.37 & 955.3 & 1953.7 & 910.9 & 1909.3 \\
\hline $\mathrm{T} 3 * \mathrm{~F} 2$ & 45.10 & 1015.7 & 2081.0 & 970.6 & 2035.9 \\
\hline $\mathrm{T} 4 * \mathrm{~F} 1$ & 43.70 & 1061.3 & 2126.0 & 1017.6 & 2082.3 \\
\hline $\mathrm{T} 4 * \mathrm{~F} 2$ & 44.03 & 1166.3 & 2544.3 & 1122.3 & 2500.3 \\
\hline $\mathrm{T} 5 * \mathrm{~F} 1$ & 44.77 & 1125.7 & 2202.0 & 1080.9 & 2157.2 \\
\hline $\mathrm{T} 5 * \mathrm{~F} 2$ & 45.23 & 1112.3 & 2388.0 & 1067.1 & 2342.8 \\
\hline SEM. & 1.08 & 35.32 & 57.06 & 35.18 & 56.53 \\
\hline Sig. & NS & NS & NS & NS & NS \\
\hline
\end{tabular}

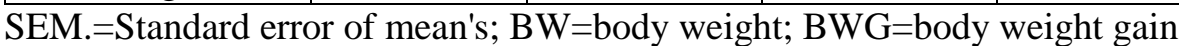
a,b,c Means in the same column followed by different letters are significantly different at $(\mathrm{p} \leq$ $0.01)$. 
Table (3): Productive response of broiler chicks to pre hatch in-ovo injection with organic iron or FeNPs and post hatch dietary folic acid supplementation

\begin{tabular}{|c|c|c|c|c|c|}
\hline Items & $\begin{array}{c}\text { FI 0-3 } \\
\text { (g) }\end{array}$ & $\begin{array}{r}\text { FI 0-5 } \\
(\mathrm{g})\end{array}$ & $\begin{array}{c}\text { FCR } \\
0-3\end{array}$ & $\begin{array}{c}\text { FCR } \\
0-5\end{array}$ & $\begin{array}{c}\text { Mortality } \\
\%\end{array}$ \\
\hline \multicolumn{6}{|l|}{ FeNPs (T) } \\
\hline Control(T1) & $1263.2^{\mathrm{a}}$ & $3624.2^{\mathrm{ab}}$ & $1.39^{\mathrm{b}}$ & $1.80^{\mathrm{b}}$ & 0.0 \\
\hline Saline(T2) & $1419.5^{b}$ & $3755.7^{\mathrm{b}}$ & $1.59^{c}$ & $1.88^{b}$ & 3.3 \\
\hline Sham(T3) & $1232.5^{\mathrm{a}}$ & $3479.2^{\mathrm{a}}$ & $1.31^{\mathrm{bc}}$ & $1.77^{\mathrm{b}}$ & 5.0 \\
\hline FeNPs (T4) & $1292.0^{\mathrm{a}}$ & $3566.2^{\mathrm{ab}}$ & $1.21^{\mathrm{bc}}$ & $1.56^{\mathrm{a}}$ & 0.0 \\
\hline Fe-Met( T5) & $1279.3^{\mathrm{a}}$ & $3590.5^{\mathrm{ab}}$ & $1.19^{\mathrm{a}}$ & $1.60^{\mathrm{a}}$ & 1.7 \\
\hline SEM. & 37.78 & 70.45 & 0.06 & 0.05 & \\
\hline Sig. & $*$ & $*$ & $* * *$ & $* * *$ & \\
\hline \multicolumn{6}{|l|}{ Folic Acid (F) } \\
\hline $\mathrm{F} 1(0.0 \mathrm{~g} / \mathrm{kg})$ & 1305.20 & 3635.1 & $1.40^{\mathrm{b}}$ & $1.84^{\mathrm{b}}$ & 3.3 \\
\hline $\mathrm{F} 2(0.5 \mathrm{~g} / \mathrm{kg})$ & 1289.16 & 3571.2 & $1.27^{\mathrm{a}}$ & $1.61^{\mathrm{a}}$ & 0.67 \\
\hline SEM. & 23.89 & 44.56 & 0.04 & 0.03 & \\
\hline Sig. & NS & NS & $* *$ & $* * *$ & \\
\hline \multicolumn{6}{|c|}{ Interaction $(\mathbf{T} * \mathbf{F})$} \\
\hline $\mathrm{T} 1 * \mathrm{~F} 1$ & 1265.3 & 3649.0 & 1.46 & 1.87 & 0.0 \\
\hline $\mathrm{T} 1 * \mathrm{~F} 2$ & 1261.0 & 3599.3 & 1.31 & 1.72 & 0.0 \\
\hline $\mathrm{T} 2 * \mathrm{~F} 1$ & 1458.7 & 3886.3 & 1.75 & 2.10 & 6.7 \\
\hline $\mathrm{T} 2 * \mathrm{~F} 2$ & 1380.3 & 3625.0 & 1.42 & 1.66 & 0.0 \\
\hline $\mathrm{T} 3 * \mathrm{~F} 1$ & 1265.0 & 3505.0 & 1.39 & 1.84 & 10.0 \\
\hline $\mathrm{T} 3 * \mathrm{~F} 2$ & 1200.0 & 3453.3 & 1.24 & 1.70 & 0.0 \\
\hline $\mathrm{T} 4 * \mathrm{~F} 1$ & 1214.0 & 3346.3 & 1.19 & 1.61 & 0.0 \\
\hline $\mathrm{T} 4 * \mathrm{~F} 2$ & 1370.0 & 3786.0 & 1.22 & 1.51 & 0.0 \\
\hline $\mathrm{T} 5 * \mathrm{~F} 1$ & 1322.0 & 3788.7 & 1.22 & 1.76 & 0.0 \\
\hline $\mathrm{T} 5 * \mathrm{~F} 2$ & 1236.7 & 3392.3 & 1.16 & 1.45 & 3.3 \\
\hline SEM. & 53.42 & 99.63 & 0.08 & 0.07 & \\
\hline Sig. & NS & $* *$ & NS & $\mathrm{NS}$ & \\
\hline
\end{tabular}

SEM.=Standard error of mean's; FI=Feed intake; FCR=feed conversion ratio a,b,c Means in the same column followed by different letters are significantly different at $(p \leq$ $0.01)$. 
Table (4): Effect of pre hatch in-ovo injection with organic iron or FeNPs and post hatch dietary folic acid supplementation on carcass yield and relative weight of some internal organs.

\begin{tabular}{|c|c|c|c|c|c|c|c|c|c|}
\hline Items & $\begin{array}{c}\text { LBW } \\
\text { (g) }\end{array}$ & $\begin{array}{l}\text { Carcass } \\
(\%)\end{array}$ & $\begin{array}{l}\text { Liver } \\
(\%)\end{array}$ & $\begin{array}{l}\text { Gizzard } \\
(\%)\end{array}$ & $\begin{array}{l}\text { Heart } \\
(\%)\end{array}$ & $\begin{array}{l}\text { Abd.Fat } \\
(\%)\end{array}$ & $\begin{array}{l}\text { Spleen } \\
(\%)\end{array}$ & $\begin{array}{l}\text { Bursa } \\
(\%)\end{array}$ & $\begin{array}{l}\text { Thymus } \\
(\%)\end{array}$ \\
\hline \multicolumn{10}{|l|}{ FeNPs (T) } \\
\hline Control(T1) & $2407^{b}$ & $70.09^{\mathrm{bc}}$ & $2.56^{\mathrm{bc}}$ & 1.13 & $0.48^{\mathrm{ab}}$ & $1.01^{\mathrm{a}}$ & $0.16^{\mathrm{ab}}$ & $0.08^{b}$ & 0.40 \\
\hline Saline(T2) & $2453^{b}$ & $67.00^{\mathrm{c}}$ & $2.23^{c}$ & 1.23 & $0.51^{\mathrm{a}}$ & $1.02^{\mathrm{a}}$ & $0.14^{\mathrm{b}}$ & $0.10^{\mathrm{ab}}$ & 0.39 \\
\hline Sham(T3) & $2260^{b}$ & $71.91^{\mathrm{bc}}$ & $2.46^{\mathrm{c}}$ & 1.24 & $0.48^{\mathrm{ab}}$ & $1.10^{\mathrm{a}}$ & $0.17^{\mathrm{a}}$ & $0.09^{b}$ & 0.39 \\
\hline FeNPs (T4) & $2810^{\mathrm{a}}$ & $81.05^{\mathrm{a}}$ & $3.06^{\mathrm{a}}$ & 1.26 & $0.43^{\mathrm{ab}}$ & $0.87^{\mathrm{ab}}$ & $0.16^{\mathrm{ab}}$ & $0.12^{\mathrm{a}}$ & 0.42 \\
\hline Fe-Met(T5) & $2813^{\mathrm{a}}$ & $78.09^{\mathrm{ab}}$ & $2.87^{\mathrm{ab}}$ & 1.10 & $0.40^{\mathrm{b}}$ & $0.76^{b}$ & $0.16^{\mathrm{ab}}$ & $0.10^{\mathrm{ab}}$ & 0.38 \\
\hline SEM. & 100.64 & 2.77 & 0.12 & 0.07 & 0.03 & 0.08 & 0.01 & 0.01 & 0.02 \\
\hline Sig. & $* *$ & $* *$ & $* * *$ & NS & NS & $*$ & $*$ & $*$ & $\mathrm{NS}$ \\
\hline \multicolumn{10}{|c|}{ Folic Acid (F) } \\
\hline $\begin{array}{l}\text { F1 } \\
(0.0 \mathrm{~g} / \mathrm{kg})\end{array}$ & 2471 & 74.2 & 2.62 & 1.18 & 0.48 & 0.96 & 0.16 & 0.09 & 0.39 \\
\hline $\mathrm{F} 2(0.5 \mathrm{~g} / \mathrm{kg})$ & 2627 & 73.0 & 2.65 & 1.21 & 0.44 & 0.94 & 0.16 & 0.10 & 0.40 \\
\hline SEM. & 63.65 & 1.75 & 0.08 & 0.05 & 0.02 & 0.05 & 0.01 & 0.01 & 0.01 \\
\hline Sig. & NS & NS & NS & NS & $\mathrm{NS}$ & NS & NS & $\mathrm{NS}$ & NS \\
\hline \multicolumn{10}{|c|}{ Interaction $\left(\mathbf{T}^{*} \mathbf{F}\right)$} \\
\hline $\mathrm{T} 1 * \mathrm{~F} 1$ & 2383 & 71.45 & 2.50 & 1.16 & 0.50 & 0.96 & 0.16 & 0.07 & 0.40 \\
\hline $\mathrm{T} 1 * \mathrm{~F} 2$ & 2430 & 68.72 & 2.62 & 1.11 & 0.47 & 1.07 & 0.17 & 0.09 & 0.39 \\
\hline $\mathrm{T} 2 * \mathrm{~F} 1$ & 2347 & 70.49 & 2.25 & 1.19 & 0.56 & 1.12 & 0.15 & 0.08 & 0.38 \\
\hline $\mathrm{T} 2 * \mathrm{~F} 2$ & 2560 & 63.50 & 2.22 & 1.27 & 0.45 & 0.91 & 0.13 & 0.11 & 0.40 \\
\hline $\mathrm{T} 3 * \mathrm{~F} 1$ & 2157 & 71.92 & 2.33 & 1.15 & 0.50 & 1.03 & 0.17 & 0.06 & 0.40 \\
\hline $\mathrm{T} 3 * \mathrm{~F} 2$ & 2363 & 71.92 & 2.59 & 1.33 & 0.47 & 1.17 & 0.17 & 0.11 & 0.37 \\
\hline $\mathrm{T} 4 * \mathrm{~F} 1$ & 2563 & 79.33 & 3.08 & 1.26 & 0.45 & 0.92 & 0.16 & 0.14 & 0.43 \\
\hline $\mathrm{T} 4 * \mathrm{~F} 2$ & 3057 & 82.81 & 3.04 & 1.26 & 0.40 & 0.82 & 0.16 & 0.10 & 0.41 \\
\hline $\mathrm{T} 5 * \mathrm{~F} 1$ & 2903 & 77.95 & 2.94 & 1.12 & 0.40 & 0.77 & 0.13 & 0.09 & 0.35 \\
\hline $\mathrm{T} 5 * \mathrm{~F} 2$ & 2723 & 78.23 & 2.80 & 1.08 & 0.39 & 0.74 & 0.18 & 0.10 & 0.40 \\
\hline SEM. & 142.32 & 3.92 & 0.17 & 0.10 & 0.05 & 0.11 & 0.01 & 0.01 & 0.02 \\
\hline Sig. & NS & NS & NS & NS & NS & NS & $*$ & $*$ & NS \\
\hline
\end{tabular}

SEM.=Standard error of mean's; LBW=Live body weight

a,b,c Means in the same column followed by different letters are significantly different at $(\mathrm{p} \leq$ $0.01)$. 
Table (5):Effect of pre hatch in-ovo injection with organic iron or FeNPs and post hatch dietary folic acid supplementation on protein fraction and lipid profile for broiler chickens.

\begin{tabular}{|c|c|c|c|c|c|c|}
\hline Items & $\begin{array}{l}\text { TP } \\
\text { (g/dl) }\end{array}$ & $\begin{array}{l}\text { Alb. } \\
\text { (g/dl) }\end{array}$ & $\begin{array}{l}\text { Chol. } \\
\text { (mg/dl) }\end{array}$ & $\begin{array}{l}\text { TG } \\
(\mathrm{mg} / \mathrm{dl})\end{array}$ & $\begin{array}{l}\text { HDL } \\
\text { (mg/dl) }\end{array}$ & $\begin{array}{l}\text { LDL } \\
(\mathrm{mg} / \mathrm{dl})\end{array}$ \\
\hline \multicolumn{7}{|l|}{ FeNPs (T) } \\
\hline Control(T1) & 4.18 & $2.21^{\mathrm{b}}$ & 170.07 & 122.37 & $46.75^{\mathrm{c}}$ & 98.84 \\
\hline Saline(T2) & 4.09 & $2.18^{\mathrm{b}}$ & 164.85 & 131.52 & $50.89^{b c}$ & 87.65 \\
\hline Sham(T3) & 4.46 & $2.75^{\mathrm{a}}$ & 163.67 & 126.92 & $54.63^{\mathrm{ab}}$ & 83.65 \\
\hline FeNPs (T4) & 4.30 & $2.21^{\mathrm{b}}$ & 167.33 & 130.62 & $59.08^{\mathrm{a}}$ & 82.13 \\
\hline Fe-Meth. ( T5) & 4.38 & $2.28^{\mathrm{b}}$ & 168.95 & 132.23 & $57.95^{\mathrm{ab}}$ & 84.55 \\
\hline SEM. & 0.15 & 0.08 & 4.75 & 3.42 & 2.42 & 5.54 \\
\hline Sig. & NS & $* * *$ & NS & NS & $* *$ & NS \\
\hline \multicolumn{7}{|l|}{ Folic Acid (F) } \\
\hline $\mathrm{F} 1(0.0 \mathrm{~g} / \mathrm{kg})$ & 4.20 & 2.30 & $172.00^{\mathrm{a}}$ & 131.45 & $51.24^{\mathrm{b}}$ & $94.47^{\mathrm{a}}$ \\
\hline $\mathrm{F} 2(0.5 \mathrm{~g} / \mathrm{kg})$ & 4.36 & 2.35 & $161.95^{\mathrm{b}}$ & 126.01 & $56.49^{a}$ & $80.26^{b}$ \\
\hline SEM. & 0.10 & 0.05 & 3.01 & 2.16 & 1.53 & 3.50 \\
\hline Sig. & NS & NS & $*$ & NS & $*$ & $* *$ \\
\hline \multicolumn{7}{|c|}{ Interaction $(\mathbf{T} * \mathbf{F})$} \\
\hline $\mathrm{T} 1 * \mathrm{~F} 1$ & 3.91 & 2.10 & 179.37 & 119.00 & 44.84 & 110.72 \\
\hline $\mathrm{T} 1 * \mathrm{~F} 2$ & 4.45 & 2.33 & 160.77 & 125.73 & 48.66 & 86.96 \\
\hline $\mathrm{T} 2 * \mathrm{~F} 1$ & 3.96 & 2.07 & 170.90 & 136.90 & 46.45 & 97.07 \\
\hline $\mathrm{T} 2 * \mathrm{~F} 2$ & 4.22 & 2.29 & 158.80 & 126.13 & 55.33 & 78.24 \\
\hline $\mathrm{T} 3 * \mathrm{~F} 1$ & 4.43 & 2.72 & 167.20 & 126.27 & 50.30 & 91.65 \\
\hline $\mathrm{T} 3 * \mathrm{~F} 2$ & 4.49 & 2.78 & 160.13 & 127.57 & 58.97 & 75.65 \\
\hline $\mathrm{T} 4 * \mathrm{~F} 1$ & 4.16 & 2.29 & 167.07 & 136.87 & 58.77 & 80.93 \\
\hline $\mathrm{T} 4 * \mathrm{~F} 2$ & 4.43 & 2.13 & 167.60 & 124.37 & 59.40 & 83.33 \\
\hline $\mathrm{T} 5 * \mathrm{~F} 1$ & 4.55 & 2.34 & 175.47 & 138.23 & 55.83 & 91.99 \\
\hline $\mathrm{T} 5 * \mathrm{~F} 2$ & 4.20 & 2.21 & 162.43 & 126.23 & 60.07 & 77.12 \\
\hline SEM. & 0.21 & 0.12 & 6.72 & 4.84 & 3.43 & 7.83 \\
\hline Sig. & NS & NS & NS & NS & NS & NS \\
\hline
\end{tabular}

SEM.=Standard error of mean's; Total protein (TP) albumin (Alb)), globulin (glob.) cholesterol (Chol.), triglycerides (TG)

a,b,c Means in the same column followed by different letters are significantly different at $(\mathrm{p} \leq$ $0.01)$. 
Table (6): Effect of pre hatch in-ovo injection with organic iron or FeNPs and post hatch dietary folic acid supplementation on hematological blood for broiler chickens.

\begin{tabular}{|c|c|c|c|c|c|c|}
\hline Items & $\begin{array}{l}\text { Hemoglobin } \\
\text { (g/100ml) }\end{array}$ & $\begin{array}{l}\text { RBC's } \\
\left(10^{6} / \mathrm{cmm}^{3}\right)\end{array}$ & $\begin{array}{l}\mathbf{H t} \\
(\%)\end{array}$ & $\begin{array}{l}\text { MCH } \\
\text { (Pg) }\end{array}$ & $\begin{array}{l}\text { MCHC } \\
\text { (g/dl) }\end{array}$ & MCVм3 \\
\hline \multicolumn{7}{|l|}{ FeNPs (T) } \\
\hline Control(T1) & $10.50^{\mathrm{b}}$ & $3.77^{b}$ & 33.98 & $27.98^{\mathrm{b}}$ & $31.14^{\mathrm{b}}$ & 90.33 \\
\hline Saline(T2) & $10.50^{\mathrm{b}}$ & $3.62^{\mathrm{b}}$ & 32.60 & $29.08^{b}$ & $32.91^{\mathrm{b}}$ & 89.93 \\
\hline Sham(T3) & $10.93^{b}$ & $3.70^{\mathrm{b}}$ & 33.26 & $29.67^{b}$ & $32.93^{b}$ & 90.11 \\
\hline FeNPs (T4) & $13.70^{\mathrm{a}}$ & $4.22^{\mathrm{a}}$ & 36.88 & $32.54^{\mathrm{a}}$ & $37.37^{\mathrm{a}}$ & 87.31 \\
\hline Fe-Meth(T5) & $13.33^{\mathrm{a}}$ & $3.90^{\mathrm{ab}}$ & 33.31 & $34.33^{\mathrm{a}}$ & $40.52^{\mathrm{a}}$ & 85.52 \\
\hline SEM. & 0.20 & 0.09 & 1.40 & 0.89 & 1.41 & 3.35 \\
\hline Sig. & $* * *$ & $* *$ & $\mathrm{NS}$ & $* * *$ & $* * *$ & NS \\
\hline \multicolumn{7}{|c|}{ Folic Acid (F) } \\
\hline $\mathrm{F} 1(0.0 \mathrm{~g} / \mathrm{kg})$ & $11.36^{\mathrm{b}}$ & 3.81 & 33.90 & $29.74^{\mathrm{b}}$ & 33.84 & 89.09 \\
\hline $\mathrm{F} 2(0.5 \mathrm{~g} / \mathrm{kg})$ & $12.23^{\mathrm{a}}$ & 3.87 & 34.11 & $31.69^{a}$ & 36.11 & 88.18 \\
\hline SEM. & 0.13 & 0.06 & 0.88 & 0.57 & 0.89 & 2.12 \\
\hline Sig. & $* * *$ & NS & $\mathrm{NS}$ & $*$ & NS & $\mathrm{NS}$ \\
\hline \multicolumn{7}{|c|}{ Interaction $(\mathbf{T} * \mathbf{F})$} \\
\hline $\mathrm{T} 1 * \mathrm{~F} 1$ & 10.20 & 3.70 & 32.50 & 27.59 & 31.62 & 88.05 \\
\hline $\mathrm{T} 1 * \mathrm{~F} 2$ & 10.80 & 3.83 & 35.46 & 28.37 & 30.66 & 92.61 \\
\hline $\mathrm{T} 2 * \mathrm{~F} 1$ & 10.20 & 3.67 & 36.25 & 27.85 & 28.40 & 98.65 \\
\hline $\mathrm{T} 2 * \mathrm{~F} 2$ & 10.80 & 3.57 & 28.96 & 30.30 & 37.42 & 81.21 \\
\hline $\mathrm{T} 3 * \mathrm{~F} 1$ & 10.60 & 3.70 & 33.35 & 28.67 & 31.83 & 90.22 \\
\hline $\mathrm{T} 3 * \mathrm{~F} 2$ & 11.27 & 3.70 & 33.16 & 30.66 & 34.03 & 90.00 \\
\hline $\mathrm{T} 4 * \mathrm{~F} 1$ & 12.93 & 3.97 & 33.62 & 32.66 & 38.49 & 84.96 \\
\hline $\mathrm{T} 4 * \mathrm{~F} 2$ & 14.47 & 4.47 & 40.13 & 32.41 & 36.25 & 89.66 \\
\hline $\mathrm{T} 5 * \mathrm{~F} 1$ & 12.87 & 4.03 & 33.79 & 31.94 & 38.87 & 83.59 \\
\hline $\mathrm{T} 5 * \mathrm{~F} 2$ & 13.80 & 3.77 & 32.82 & 36.72 & 42.16 & 87.44 \\
\hline SEM. & 0.29 & 0.13 & 1.97 & 1.27 & 2.00 & 4.73 \\
\hline Sig. & NS & NS & $*$ & NS & NS & NS \\
\hline
\end{tabular}

SEM.=Standard error of mean's;Red blood cells count (RBC), hemoglobin (Hb), Mean Corpuscular Hemoglobin (MCH) and Mean Corpuscular Hemoglobin Concentration (MCHC) a,b,c Means in the same column followed by different letters are significantly different at $(\mathrm{p} \leq$ $0.01)$. 
Table (7): Effect of pre hatch in-ovo injection with organic iron or FeNPs and post hatch dietary folic acid supplementation on globulin fractions, tri-iodothyronine and transferrin for broiler chickens.

\begin{tabular}{|c|c|c|c|c|c|}
\hline Items & $\begin{array}{l}\text { àglob. } \\
\text { (mg/ml) }\end{array}$ & $\begin{array}{l}\text { BGlob. } \\
(\mathrm{mg} / \mathrm{ml})\end{array}$ & $\begin{array}{r}\gamma \text { Glob. } \\
(\mathrm{mg} / \mathrm{ml})\end{array}$ & $\begin{array}{l}\text { T3 } \\
\text { (ng/ml) }\end{array}$ & $\begin{array}{l}\text { TF } \\
(\mathrm{mg} / \mathrm{ml})\end{array}$ \\
\hline \multicolumn{6}{|l|}{ FeNPs (T) } \\
\hline Control(T1) & $27.20^{\mathrm{b}}$ & $57.30^{\mathrm{b}}$ & $77.62^{b}$ & $2.94^{\mathrm{b}}$ & $1.45^{\mathrm{b}}$ \\
\hline Saline(T2) & $28.08^{b}$ & $61.05^{\mathrm{b}}$ & $80.38^{\mathrm{b}}$ & $3.20^{\mathrm{ab}}$ & $1.51^{b}$ \\
\hline Sham(T3) & $29.83^{b}$ & $61.70^{\mathrm{b}}$ & $83.45^{\mathrm{b}}$ & $3.42^{\mathrm{ab}}$ & $1.49^{\mathrm{b}}$ \\
\hline FeNPs (T4) & $68.47^{\mathrm{a}}$ & $81.20^{\mathrm{a}}$ & $92.78^{\mathrm{a}}$ & $3.63^{\mathrm{a}}$ & $2.20^{\mathrm{a}}$ \\
\hline Fe-Meth.( T5) & $72.57^{\mathrm{a}}$ & $88.97^{\mathrm{a}}$ & $94.37^{\mathrm{a}}$ & $3.85^{\mathrm{a}}$ & $2.31^{\mathrm{a}}$ \\
\hline SEM. & 2.75 & 3.14 & 2.45 & 0.21 & 0.09 \\
\hline Sig. & $* * *$ & $* * *$ & $* * *$ & $* *$ & $* * *$ \\
\hline \multicolumn{6}{|l|}{ Folic Acid (F) } \\
\hline $\mathrm{F} 1(0.0 \mathrm{~g} / \mathrm{kg})$ & $39.46^{\mathrm{b}}$ & $63.83^{\mathrm{b}}$ & $81.19^{b}$ & $3.22^{b}$ & $1.67^{\mathrm{b}}$ \\
\hline $\mathrm{F} 2(0.5 \mathrm{~g} / \mathrm{kg})$ & $51.00^{\mathrm{a}}$ & $76.26^{\mathrm{a}}$ & $90.31^{\mathrm{a}}$ & $3.59^{\mathrm{a}}$ & $1.91^{\mathrm{a}}$ \\
\hline SEM. & 1.74 & 1.99 & 1.55 & 0.12 & 0.06 \\
\hline Sig. & $* * *$ & $* * *$ & $* * *$ & $*$ & $* *$ \\
\hline \multicolumn{6}{|l|}{ Interaction $(\mathbf{T} * \mathbf{F})$} \\
\hline $\mathrm{T} 1 * \mathrm{~F} 1$ & 22.00 & 50.53 & 72.40 & 2.78 & 1.37 \\
\hline $\mathrm{T} 1 * \mathrm{~F} 2$ & 32.40 & 64.07 & 82.83 & 3.11 & 1.52 \\
\hline $\mathrm{T} 2 * \mathrm{~F} 1$ & 21.47 & 54.33 & 75.13 & 3.04 & 1.56 \\
\hline $\mathrm{T} 2 * \mathrm{~F} 2$ & 34.70 & 67.77 & 85.63 & 3.35 & 1.45 \\
\hline $\mathrm{T} 3 * \mathrm{~F} 1$ & 22.47 & 56.53 & 76.23 & 3.34 & 1.33 \\
\hline $\mathrm{T} 3 * \mathrm{~F} 2$ & 37.20 & 66.87 & 90.67 & 3.50 & 1.65 \\
\hline $\mathrm{T} 4 * \mathrm{~F} 1$ & 63.77 & 74.77 & 89.70 & 3.26 & 2.06 \\
\hline $\mathrm{T} 4 * \mathrm{~F} 2$ & 73.17 & 87.63 & 95.87 & 4.01 & 2.35 \\
\hline $\mathrm{T} 5 * \mathrm{~F} 1$ & 67.60 & 82.97 & 92.17 & 3.70 & 2.04 \\
\hline $\mathrm{T} 5 * \mathrm{~F} 2$ & 77.53 & 94.97 & 96.57 & 4.00 & 2.57 \\
\hline SEM. & 3.89 & 4.44 & 3.47 & 0.30 & 0.13 \\
\hline Sig. & NS & NS & NS & NS & NS \\
\hline
\end{tabular}

SEM.=Standard error of mean's Transferrin (TF) Triiodothyronine (T3)

a,b,Means in the same column followed by different letters are significantly different at $(\mathrm{p} \leq$ $0.01)$. 


\section{REFERENCES}

Abd El-Azeem, N. A.; M. S. Abdo; M. Madkour and I. El-Wardany, 2014. Physiological and histological responses of broiler chicks to in-ovo injection with folic acid or 1-carnitine during embryogenesis. Glob Vet 13(4):544-551.

Aoyagi, S. and D. H. Baker, 1993. Nutritional evaluation of a coppermethionine complex for chicks. Poult. Sci., 72, 2309-2315.

Bakyaraj, S.; K. Subrat; S. BhanjaS and B. D. Majumdar, 2012. Modulation of post-hatch growth and immunity through in-ovo supplemented nutrients in broiler chickens. Society of Chemical Industr. 92, (2): 313-320.

Barroeta, A. C.; G. Gonzalez; J. sanz and R. Cepero Briz, 2012. Optimum vitamin nutrition in poultry breeders, in Optimum vitamin nutrition; in the production of quality animal foods.5M Publishing: United Kingdom. p. 41-87.

Bossuyt, X., 2006. Advances in serum protein electrophoresis. Adv Clin Chem 42: 43-80

Bronstein, L. M.; X. Huang; J. Retrum; A. Schmucker;M. Pink;B. D. Steinand B. Dragnea, 2007. Influence of Iron Oleate Complex Structure on Iron Oxide Nanoparticle Formation. Chem. Materials, 19, 3624-3632.

Cai M.-Q.; Z. H. Ling and L. R. Dai, 2012. Target-filtering model based articulatory movement prediction for articulator control of HMM-based speech synthesis. In Signal Processing (ICSP), IEEE 11th International Conference, 1, pages 605-608.

Choi, J. S.; I. U. Koh; H. J. Lee; W. H. Kim; J. Song, 2013. Effects of excess dietary iron fat on glucose lipid metabolism. The Journal of Nutritional Biochemistry 24, 1634-1644.

Choupani, H.; S. SIadat; M. kazempour; R. Rahimi and M. M. hasanvand, 2013. Increase Learning in Organizations by playing the role of transformational leadership (Isfahan University of Medical Sciences). Journal of Health Administration, 16, pp. $15-28$

Cowey, C. B. and B. Woodward, 1993. The Dietary Requirement of Young Rainbow Trout (Oncorhynchus mykiss) for Folic Acid. J Nutr 123: 1594-1600.

Diamond, S. M.; A. Dobracki; S. Freitag; J. D. S. Griswold; A. Heikkila; S. G. Howell; M. E. Kacarab; J. R. Podolske; P. E. Saide and R. Wood, 2018. Time-dependent entrainment of smoke presents an observational challenge for assessing aerosol-cloud interactions over the southeast Atlantic Ocean. Atmos. Chem. Phys., 18, 14623-14636. https://doi.org/10.5194/acp-18-146232018

Doumas, B. T.; D. D. Bayso; R. J. Carter; T. Peter and R. Schaffer, 1981. Determination of serum albumin. Clin. Chem. 27:1642-1643.

El-Husseiny , O.M. ; M.A. Abo-El-Ella ; M.O. Abd-Elsamee and Magda, M. Abd-Elfattah, 2007. Response of Broilers Performance to Dietary Betaine and Folic Acid. International Journal of Poultry Science 6 (7): 515523.

Finch, C. A.; J. D. Cook; R. D. Labbe and M. Culala, 1977. Effect of Blood Donation on Iron Stores As Evaluated by Serum Ferritin. Blood, 50, No. 3: 441-447.

Fossati, P.; and L. Prenciple, 1982. Serum triglycerides determined 
nano-particles elements - broiler performance - physiological response.

colorimetrically with an enzyme that produces hydrogen peroxide. Clin. Chem., 28, 2077-2080.

Fox, P. L., 2003: The copper-iron chronicles. The story of an intimate relationship. BioMetals. 16, 9-40.

Foye, O. T.; Z. Uni; P. R. Ferket, 2006. Effect of in-ovo feeding egg white protein, $\beta$ - hydroxy- $\beta$-methylbutyrate, and carbohydrates on glycogen status neonatal growth of turkeys. Poult Sci. 85:1185-1192.

Friedewald, W. T.; R. I. Levy and D. S. Fredrickson, 1972. Estimation of the concentration of low-density lipoprotein cholesterol in plasma, without use of the preparative ultracentrifuge. Clin Chem., 18, 499502.

Grant, G. H.; L. M. Silverman and R. H. Christenson, 1987. 3th Ed., WB Saunders Company; Philadelphia: WB Saunders; 291-345.

Halver, J. and R. Hardy, 2002. Fish Nutrition (3rd Ed), 839.

Halver, J. E., 1989. The vitamins. In: Fish Nutrition, (2ndedn), Academic Press, New York, USA.

Harper, A. E.; N. J. Benevenga and R. M. Wohlhuete, 1970. Effects of ingestion of disproportionate amounts of amino acids. Physiol Rev.;50:428558.

Hutson, S. M.; A. E. Harper, 1981. Blood and tissue branched-chain amino and $\alpha$-keto acid concentrations: Effect of diet, starvation, and disease. Am. J. Clin. Nutr., 34:173-183.

Isabel, B.; A. I. B. Rey and C. Lòpez, 2012. Optimum vitamin nutrition in pigs, in Optimum vitamin nutrition; in the production of quality animal foods, 5M Publishing: United Kingdom. p. 243-306.
Ji, F.; W. Q. Ma; Z. R. Xu;J. X. He, Y.

Z. Wang and J. X. Liu, 2009. The effect of iron glycine chelate on tissue mineral levels, fecal mineral concentration, and liver antioxidant enzyme activity in weanling pigs. Animal Feed Science and Technology, 150, 106-113.

Ji, F.; W. Q. Ma; Z. R. Xu;Y. Z. Wang and J. X. Liu, 2007. Effects of iron glycine chelate on growth, haematological and immunological characteristics in weanling pigs. Animal Feed Science and Technology, 134, 261-272.

Kwiecień, M. ; W. Samolińska and B. Bujanowicz-Haraś, 2015. Effects of iron-glycine chelate on growth, carcass characteristic, liver mineral concentrations and haematological and biochemical blood parameters in broilers.Journal of Animal Physiology and Animal Nutrition(99) 1184-1196.

Li, M. and C. Zhao, 2009.Study on Tibetan chicken embryonic adaptability to chronic hypoxia by revealing differential gene expression in heart tissue. Sci. China C. Life Sci., 52: 284-295.

Lopez-Virella, M. F., P, Stone, S. Ellis and J. A. Colwell, 1977. Cholesterol determination in high-density lipoproteins separated by three different methods. Clin Chem 23, (5) 882-884

Lozoff, B.; N. Kacirot and T. Walter, 2006. Iron deficiency in infancy: Applying a physiologic framework for prediction. Am. J. Clin. Nutr. 84, 14121421.

Marinov, B., 2011. Modern Aspects for Assessment of the Nutritional Value of the Raw Materials for Mixed Feed. Feed and Feeding, 3: 6-7 . 
Menendez, C.; E. Kahigwa; R. Hirt; P. Vounatsou; J. J. Aponte; F. Font and C. J. Acosta, 1997. "Randomised placebo-controlled trial of iron supplementation and malaria chemoprophylaxis for prevention of severe anaemia and malaria in Tanzanian infants." Lancet 350 (9081):844-50. doi: 10.1016/s01406736(97)04229-3.

Mittra, B.; M. Cortez; A. Haydock; G. Ramasamy; P. J. Myler and N. W. Andrews, 2013. Iron uptake controls the generation of Leishmaniainfective forms through regulation of ROS levels. J Exp Med. 2013;210(2):40116.

Mogahid, A. A.; Gh .G. Gad; E. A. Abdalla and I. El-wardany, 2019. Influence of in-ovo injection of inorganic iron and its nanoparticles form on growth, and physiological response of broiler chickens. 14th Conf. Agric. Develop. Fac. of Agric. Ain Shams Univ. 27: 12- 22, Egypt.

Mullally, A. M.; G. B. Vogelsang and A. R. Moliterone, 2004. Warted sheep and premature infants the role of trace metals in hematopoiesis. Blood Rev. 18, 227-234.

Nouri, S.; J. G. Ghalehkandi, S. Hassanpour and H. AghdamShahryar, 2018. Effect of In-ovo Feeding of Folic Acid on Subsequent Growth Performance and Blood Constituents Levels in Broilers. International Journal of Peptide Research and Therapeutics. 24, Issue 3, pp 463-470

NRC; National Research Council, 1994. Nutrient Requirements of Poultry. 9th rev. ed., National Academy Press, Washington, DC.

Pek, H.; M. Avci; M. Yertk and N. Aydlek, 2005. Effects of copper and iron addition to diets on growth performance and some blood parameters in quail. VeterinerBilimleriDergisi, 21 (1/2): 4550.

Quintana, L.; A. Monasterio; K. Escuredo,K.; J. del Amo; P. Alfonso; F. Elortza; S. Santa Cruz; L. Simon; A. Martinez; P. Giraldo; M. Pocovı and J. L. Castrillo, 2006. Identification of chitotriosidaseisoforms in plasma of gaucherdiseasepatients by two dimensional gel electrophoresis.Biochimica et Biophysica Acta(BBA)-Proteins and Proteomics1764,1292-1298.

Sahin, K.; M. Onderci; N. Sahin; M. F. Gursu and O. Kucuk, 2003. Dietary Vitamin $\mathrm{C}$ and Folic Acid Supplementation Ameliorates the Detrimental Effects of Heat Stress in Japanese Quail. J. of Nutr. 133: 18821886.

SAS., 2006. Statistical Analysis System, SAS User's Guide. Statistics SAS institute Inc., Cary, NC, USA.

Schumacher, Y. O.; A. Schmid; D. König and A. Berg,2002. Effects of exercise on soluble transferrin receptor and other variables of the iron status. Br. J. Sports Med.; 36:195-200

Shinde, P. L.; S. L. Ingale; J.Y. Choi; J. S. Kim; S. I. Pak and B. J. Chae, 2011. Efficiency of inorganic and organic iron sources under iron depleted conditions in broilers. $\mathrm{Br}$. Poult Sci. 52, 578-583.

Soheil, L.; K. Hossein; N. Shabanali; B. Mohammad; M. Mehdi and A. Firouz, 2013. The Effects of Folic Acid Treatment on Biometric and Blood Parameters of Fingerling Rainbow Trout Fishes (Oncorhynchus mykiss) Firouz et al., J. Aquac. Res. 
nano-particles elements - broiler performance - physiological response.

Development, 4, (3): 175. DOI: 10.4172/2155-9546.1000175.

Sosnowska, N. M.; M. Batroska; W. Agnieszka; E. Sawosz; S. Jaworski and J. Nieemiec, 2013. Effect of nanoparticles of copper and copper sulfate administered in-ovo on hematological and biochemical blood markers of broiler chickens Animal Science No 52 : 141-149.

Stein, O.; Y. Stein; M. Lefevre and P. S. Roheim, 1986. The role of apolipoprotein A-IV in reverse cholesterol transport studied with cultured cells and liposomes derived from an ether analog of phosphatidylcholine. Biochim Biophys Acta. 14;878(1):7-13.

Talpur, H. S.; I. Shafi; R. Dad; D. Bhattarai; Z. Rehman; F. Ullah; and A. A. Ullah, 2016. Effects of supplementation of ferrous sulphate (iron) on the growth of hubbard broiler chicks. Sci.Int.(Lahore),28(5),46874692.

Uni, Z.; P. R. Ferket; E. Tako and O. Kedar, 2005. In-ovo feeding improves energy status of late-term chicken embryos. Poultry Science. 84, 764-770.

Wedekind, K. J.; A. E. Hortin and D. H. Baker, 1992. Methodology for assessing zinc bioavailability: efficacy estimates for zinc-methionine, zinc sulfate, and zinc oxide. Journal of Animal Science, 70, 178-187.

Whitnall, M.; D. R. Richardson, 2006. Iron: A new target for pharmacological intervention in neurodegenerative diseases. Seminars Pediatric Neurol. 13, 186-197.

Zhai, W.; D. E. Rowe and E. D. Peebles, 2015. Effects of commercial in-ovo injection of carbohydrates on broiler embryogenesis. Poultry Science, 90 :1295-1301. 


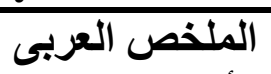

تأثير حقن البيض بخلات مثيونين الحديد أوالجزيئات الناتومترية للحديد و عليقة حمض الفوليك

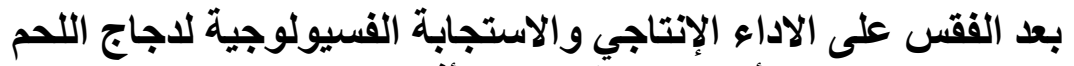

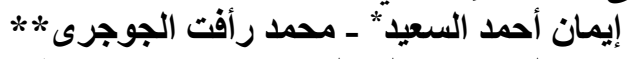

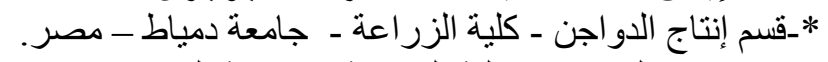

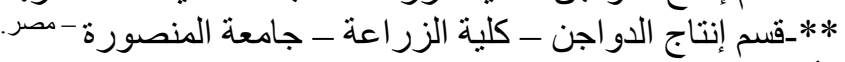

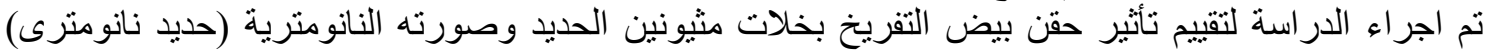

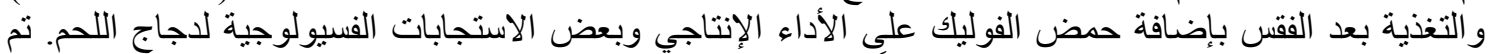

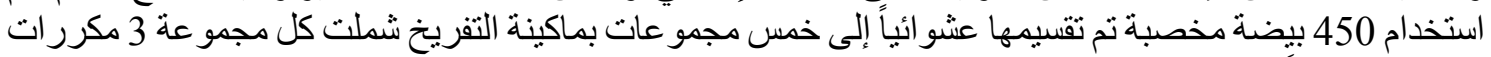

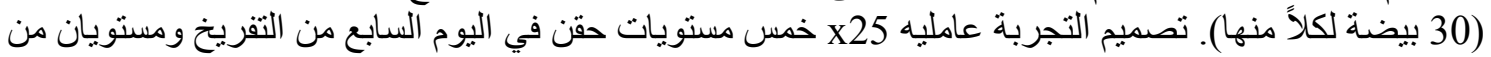
إضافة حمض الفوليك للعليقة (صفر، 0.5 جم / كجم عليقة) بعد الفقس. معاملات الحقن تم تقسيمها لخمس مجمو عات التهات

المجيموعة الأولى( الكنترول السالبة): لم يتم حقنها، و المجمو عة الثانية: تم حقنها بـ 0.1 مل/بيضة محلول فسيولوجي

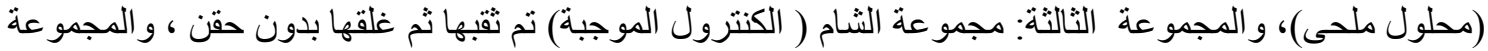

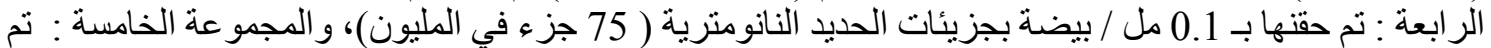

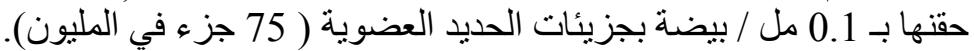

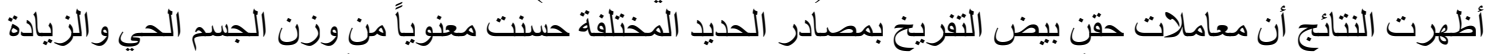

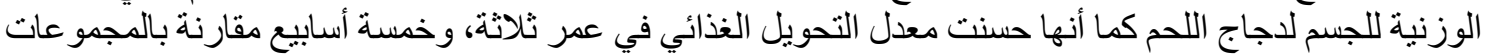

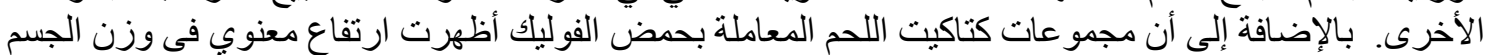

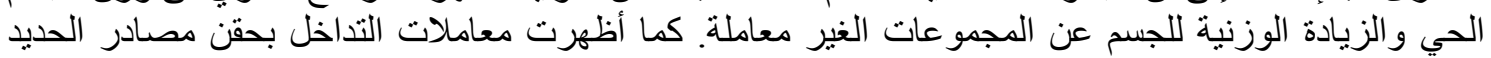

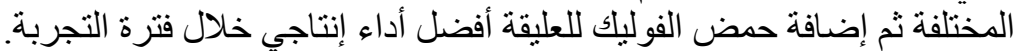

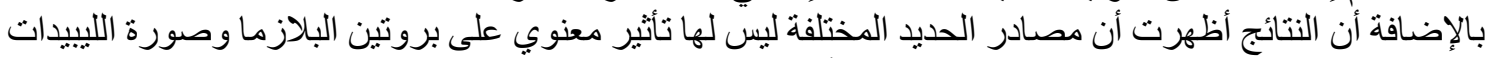

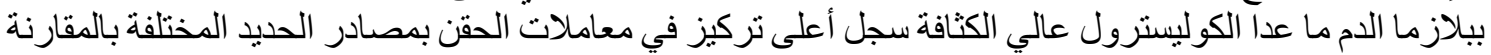

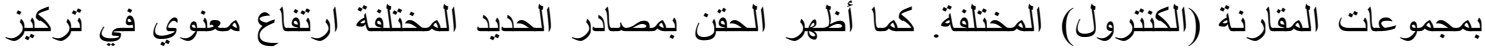

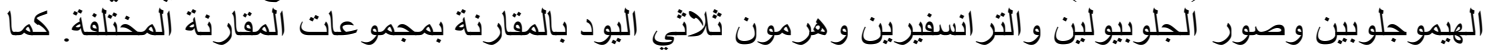

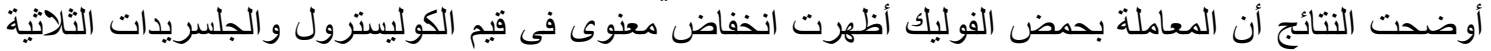

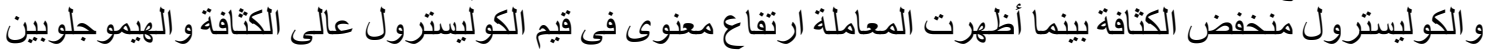

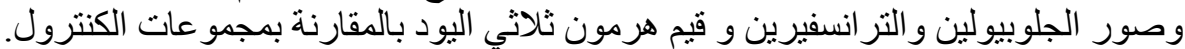

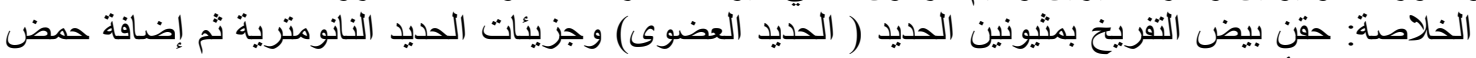
الفوليك للعليقة أدت لتحسين الاستجابة الإنتاجية و الفسيولوجية (لكيد لكتاكيت اللحم. 